\author{
Ahmedova A. A., \\ Ph.D. in Philology, \\ Senior Teacher of the Department of the Azerbaijani Language \\ Ganja State University
}

\title{
MEANING PATTERNS OF THE POSTPOSITION “ILӘ” (WITH) IN AZERBAIJANI LANGUAGE
}

Summary. Postpositions are auxiliary parts of the speech that have historically formed independent words. The transformation of independent words into auxiliary words is accompanied by the emergence of new categorical meanings. Converting one unit into another in a constantly evolving language is a product of natural development, and as a result, the language becomes enriched and more functional. The formation of auxiliary parts of the main parts of the speech is also part of this process.

The emergence of auxiliary parts of the speech is, of course, related to the emergence of abstractions, the greater motivation of language material in the later development of the language. The auxiliary parts of the speech do not only function as a combination of words in a sentence, but also to form different grammatical meanings, and to add lexical and semantic content to the structure they enter. This is directly related to their initial position and destination.

The same postposition within a function can express different meanings. In this case, postposition is associated with the same event and performs the same functional-grammatical function and is the leading content in its relation to any word. At the same time, the meaning of the shades within the overall content is also apparent. From this point of view, postposition "with" is more attractive.

Postposition "with" can express many meanings depending on the context: 1. It expresses the context of co-existence. 2. Provides the content of the method with the word combined. 3. Some words used in postposition "with" have the accompanied content. 4. One of the meanings expressed by the postposition "with" combined with the word is the meaning of cause. 5. Provides "time object content". 6. When dealing with words with spatial context, different shades of meaning emerge, most importantly, refers to the concept of space in which movement occurs.

Key words: grammatical meaning, semantic features, accompanying, time content.

Introduction. The postpositions are part of auxiliary parts of speech that has historically been derived from independent words. The transformation of independent words to auxiliary words is accompanied by the emergence of a new categorical meaning [1, p. 162]. Converting a unit into another unit in a constantly evolving language is a product of the natural process of development and, as a result of this process, the language becomes enriched and becomes more effectively functional. The creation of auxiliary speech parts from the main parts of speech is also part of this process.

Creation of auxiliary speech parts, of course, is related to the formation of abstracts during the subsequent development of language, and more motivation of the language material. Abstracting is accompanied not by the release of lexical-semantic load, but rather a compression and ability to concentrate different functions through this compression. We can also observe it in the process of emerging of auxiliary parts of speech. Thus, auxiliary speaking parts do not only combine the words in the sentence, perform functions of formation of different grammatical meanings, but also incorporate lexical-semantic content, pattern in the structure, in which it included. This is directly related to their initial condition, purpose. There is enough information on this in the linguistic literature.

Within the functional context, the same postposition can express different meanings. At that the postposition is linked to the same case and performs the same functional-grammatical task and becomes a leading content in its link with any word. In addition, the pattern meanings are also reflected within the overall content. From this point of view, "ilə" (with) postposition draws more attention.

Main material. As is well known "ila" (with) postposition has a different meaning, which is directly related to the meaning of the word that it attached to. Linguistics works shows that this postposition creates several patterns: togetherness, accompaniment, medium, space, time and so on. [2, p. 415; 3, p. 86]. A. Shukurov has noted that this postposition historically express work, quantity of movement, quality, exchange and so on, in addition to accompaniment, togetherness context. [4, p. 25].

The "ila" (with) postposition is used with different words and participates in the appearance of colorful meaning patterns. However, regardless of with what word they are used, all of the examples have potentially togetherness content, and it is not accidental that in all the relevant works this postposition is shown as "togetherness" postposition. Thus, in the expressions formed with participation of this postposition the active or non-active union of several subjects or the union of subject and object in different ways are indicated.

The combination of subjects with the participation of this postposition also has different characteristics. In some cases, subjects will have a functionally equal load. At this point, the postposition performs the function of "ila" (with) postposition functionally. However, if at this position the "ilo" (with) is ignored, then the wrong idea will appear. It should be noted that the word "ila" (with) used at this point is presented as an postposition by some linguists, despite different functionality [4, p. 25]. A. Shukurov notes: "The "ila" (with) postposition at the same time also fulfilled the task of uniting conjunction in the medieval Azerbaijani language: Bu saval ila bu cavab nadir? "(orada)(What is this answer for this question?" (there). At this point it would be wrong to call the "ilo" (with) morpheme as a postposition. The same postposition 
with conjunction is very similar to each other; the binding function of their components is also appropriate. But it should be taken into consideration that the words that create connection with the postpositions are subordinate to each other; so that the word with attached postposition is dependent on the word that is attached with: the dependent component in the word combination, the secondary in the sentence, i.e. the dependent member (object or adverbial modifier). In the example above, we observe another scene. Here the morpheme "ila" (with) has been used between equal rights words and has served to their closer binding. It is no coincidence that although it is impossible to separate the postposition from the word attached, it is not difficult to remove the conjunction from its place of attribution, it can be removed and replaced with comma, and in the pronunciation the enumeration inflexion is used.

It should also be mentioned here that the using of "ill" (with) as postposition or conjunction is directly influenced by the conforming of subject to predicate. Let's compare two facts: 1. Adil ila man kitabxanaya gedirdik; 2. Adil manimla kitabxanaya gedirdi. (1. I was going to the library with Adil; 2 . Adil was going to the library with me.) In the first sentence, the words "Adil" and "I" are homogenous. Therefore, the predicate was conformed to them by persons and quantity and used in the plural of the first person. Since the second sentence does not have any homogenous subjects (here' Adil is subject and the word "mənimla" (with me) is indirect object), the predicate is conformed to word "Adil", which is the only subject of the sentence, for person and quantity, and was used in the singular of the third person. From this point of view, it is necessary to speak not only about the word "“illa" (with) acting as conjunction, while being a postposition, also being as postposition and conjunction being homonym.

It should be noted that at both moments a subject may not be used, but the fact of the word with postposition being joint subject (homogenous subject) or object is understood from the personal suffix of predicate in the sentence. Thus if the predicate is in plural of the first person, the missed member is the homogenous subject, i.e. the joint subject, because if there are pronouns of the first person within the homogenous subjects, the predicate will be in the plural of the first person. If the predicate is in singular in this sentence, the missed member is a indirect object, that is, object, because since the word with postposition is object, the restored word "mən"(I) is subject in singular, and therefore the predicate is conformed to it and is in singular of first person. Let's compare: 1. Dostumla yarışa qatıldıq; 2. Dostumla yarışa qatıldım. (We participated in the competition with my friend; 2 . I joined the competition with my friend). In the first of these examples the restored word " $m ə n$ "(I) is homogenous subject (joint subject), and in the second it is indirect object (object).

Let's also say that, in this case, "ila" (with) postposition has two types of using, which is related to the location of word with postposition in the sentence, or more precisely, with the actualization. In the first case, the word with postposition comes near the subject having the subject function and at that the degree of conformity between the subject and object is very close: Cavad amisi ila kando getdi (Jawad went to the village with his uncle). In the latter case, the word with postposition comes not near the immediate subject, but it is relatively far and at that the conformity to the subject becomes weakened: Cavad kanda amisi ila getdi (Javad went to the village with his uncle). In these examples with same lexical, even grammatical view, the semantic pattern of words with postposition is different. Thus, in the first sentence, the content of the joint action of subject and the object with postposition is in the foreground and in the second sentence the content is in back, here the medium content is stronger, because in the latter moving of word with postposition to the end is related to its actualization. That word, which is actualized, is essentially different from the subject.

Certainly, the main meaning patterns given to word by "ild" (with) postposition, to which it is attached is togetherness; This is due to the semantics of the word that is derived from that particular postposition, although from time to time the new meaning patterns resultant from abstraction are formed, the initial meaning is also preserved. Therefore, regardless of what patterns express this postposition in addition, the togetherness content here is expressed in some degree. However, other patterns, depending on the lexicalsemantic nature of the word it attached to, also show itself. We will try to explain the other patterns of this postposition by concrete examples.

1. Gülgaz bu kiçik balası ila çox xoşbaxt hayat yaşayırdl. (M.ibrahimov) (Gulgaz lived a very happy life with this little child. (M. Ibrahimov))

Here "ill" (with) postposition expresses the content of the ogetherness, but this does not mean that this togetherness is execution of any work by two subjects on equal rights; the mother related action is active, and the child related action is inactive. More precisely, the mother is the subject and the child is the object in that idea.

In this type of connection, different content patterns manifest itself in other samples. For example: Cavid Solmaz ila xosbaxt idi (Javid was happy with Solmaz). The togetherness here is different from the first sentence; as though the work relates directly to the fact that the first person is an active subject, but the object, on the contrary, has no link with inactive action. In the first sentence, the subject is associated with object more than the predicate (Gülgaz kiçik balası ila-Gulgez with the little child). That is why the word "birlikdə" (together) can be used in the first sentence: Gülgzz bu kiçik balası ila birlikdə xoşbəxt yaşayırdı. ( Gulgaz was happy with this little baby).

In the next sentence, the subject is associated with a feature of predicate function rather than object (Cavid xoşbəxt idi (Javid was happy)). That's why it seems unreasonable to add the word "birlikd"'(together) here. This is related to the fact that in the first sentence, the content of the togetherness between the subject and the object is stronger and closer to equitable subjects. It cannot be said about the second sentence.

The connection between the subject and the object in such type of sentences may be in the aspect of approval and denial; in the aspect of denial, the content of togetherness is weakened more. For example: Bu masalada mən saninla razilaşa bilmərəm (In this matter, I cannot agree with you). Here's the word "səninla" (with you) in the exact sense is of the object nature, and the content of the togetherness does not draw attention.

2. Firidun alindəki çəkicla mismarı taxtaya vurmaq istayirdi ki, küçadan tükürpadici qışqurtı eşitdi (S.Ohmədov). (Firidun wanted to nail to the wood in his hand m suddenly a spitting shout came from the street (S.Ahmadov)).

In this example, the postposition gave a content of tool, medium to word, to which it is attached. Here, it would not be right to look for togetherness content in the real sense of the word. Thus, the work with postposition attached to it has a function of lifeless object in the sentence, in this sense it cannot be equal to the subject having the human content. 
There is a need to distinguish between these similar examples. That is, at first glance, there are sentences that give the impression of the medium, the content of the tool, but actually they have other content. For example: İki nəfərin arxa qapıdan çıxdığını öz gözlarimla gördüm. (I saw two people coming out from the back door with my own eyes). The expression "öz gözlarimla" (with my own eyes) is, of course, seems unusual for the semantics of sentence, unnatural, abnormal in terms of literary language, the logic of use of the word in the sentence has been violated. This sentence actually should have been used without this expression: İki nəfərin arxa qapıdan çıxdı̆ğnı gördüm (I saw two men coming out the back door). In this sentence with predicate in past indefinite tense, the expression "öz gözlarimla" (my own eyes) with content of witnessing further strengthens the absoluteness. Hence, these words should be regarded as "empty words" in lexical-semantic terms.

Which pattern means this expression, used with postposition, is defined by these two positions. So, the visibility of fact shows the content of the tool, medium, but since the content of vision itself related to eye, it does not have a separate content load for the sentence. This indicates that in the same sentence this word does not fulfill the content of the tool, medium.

The use of this expression serves to enhance emotionallyexpressive pattern, to increase the sentence's credibility, rather than width of the information. From this point of view, it is not possible to mention that "-la" (with) postposition means the tool or medium. The lack of this function is not related to the postposition, but the position of the expression it attached to in the sentence and the degree of necessity.

The words and phrases with attached to them "ila" (with) postposition are colorful in content; their attachment with postposition creates a large number of associated patterns within a general context. For example, the word "çəkicla" (with hammer) in the example "mismarl çəkiclə vurdu" (nailing with hammer) and word "maşılla" (with a car) in the example "kondo maşınla getdi" (went to village with a car) means a tool, a medium. However, these tools are substantially different from each other. Although both are objects, the latter has an active position in terms of relevance. So the hammer is tool and the medium and the car is a tool, but a medium.

3. Some words used with the "ilə" (with) postposition have the content of an object with medium. At this time, the word with postposition must be static in relation to the associated word. For example: Stəkan su ila dolu idi; Raflar köhna kitablar ila doludur (The glass was full of water; Shelves are full of old books).

Words with postpositions that have indirect object content are sometimes associated with an abstract concept. For example: Mən Vatznimla faxr edirzm (I am proud of my Motherland). Here, instead of the word "Vətənimla" (with Motherland), it is possible to use different words: atamla, qalabalarimla va s. (with my father, with my victories and so on). Apparently, the manifestation of the indirect object content in this type of words with postposition depends largely on the word that it is attached to, in particular the verb.

4. There is such a famous saying in our language: "Azərbaycan iri addlmlarla iralilayir".("Azerbaijan is moving forward with great steps"). Although the word "addimlarla" (with steps) here means the content of the tool, medium, this content is not concrete but abstract. It is necessary to note that this sentence is necessary for the sentence and it is impossible to formulate the sentence without it. However, this expression is more of a manner content than object feature. As you can see from the example, though the word "addlm" (step) is an object, but its relation to the word "iri" (big) changes the character of the object and transforms to manner content. It is no coincidence that the word, which is an object, cannot be used without attribute, so the unity of these two words occurs.

Part of this type of expression, formulated with the participation of this postposition and having the manner content, does not seem to be logical, even if the tool does not appear to contain the content. For example: Bu işin nə naticə veracəyini ağllla düşünmək lazımdır (It is wise to consider the consequences of this work). In fact, reasoning is linked to brains, there is no thinking without brains. Within the content of this sentence there is not "ağglla düş̈̈nmək" (thinking intelligently) but there is a conception of "yaxșı düșünmək" ("thinking well"), and in the simplest case, generally "düşünmək" (to think). Hence, the word with postposition "brains" have not been used in its full lexical meaning, but served to create an emotionallyexpressive pattern.

Having a tool or manner content of expression of this type is related to their situational position. This means that there are expressions which are used with so-called postposition, having at one point a medium and at other manner content. For example: 1. 1.Xəyal ila ciddi uğurlara nail olmaq mümkün deyil; 2. Xəyal ila yaşamaq zaiflik, iradasizlik alamotidir. It is impossible to achieve serious successes with the dream; 2. Living with a dream is a sign of weakness, lack of will.

In the first example, the expression "xayal ila" (with the dream) has a tool, medium meaning and requires a question $n$ ə ilo? (what with). It also shows itself in the general context of the sentence; it shows the means of achieving something, so it is possible to present this phrase as "xayal vasitzsila" (through dream). In the second sentence that expression does not require the question na ila (what with), but necə? (how) question may be asked. So if there is manner context, we cannot speak about the tool, medium content.

The latter idea can be strongly stated in regard of the following sentence: Bu cür sualin verilacayini gözlaməyən Cavahir qaribəifada ila cavab verdi (H.Ibrahimov). (Jawahir, who did not expect such a question, responded with strange expression (H. Ibrahimov)). In this sentence, the phrase "qoribz if ad 2 ila" (with strange expression) only expresses the content of the manner. This is interesting in terms of reflecting the evolution of "ila" (with) postposition. More precisely, this postposition has grown to the meaning of the manner from tool, medium meaning. Today the suffix $-l a,-l$, which create manner-action adverb is the product of this development, that is, it has been formed from postposition.

One issue draws attention. In some of the works, the adverbs formed using -la, -la suffixes are also presented as a postposition. A.Hasanov writes about the means of expression of adverb: "When abstract nouns are used with this and secondary kind of defining word combinations with (-la, -la) postpositions, they become adverbial modifier of action manner. For example: Araz dağlar yarıb qayalar dəlir; Zamann fikri tək axır süratlo (S.Vurğun); Ana onları öz uşaqları kimi mehribanliqla qarşıladı (M.İbrahimov)" [5, p. 151]. (The Araz cleaves the mountains and hit the rocks; The idea of time flows alone with speed (S. Vurgun); The mother welcomed them kindly as her own children (M. Ibrahimov)" [5, p. 151].

As you can see, the words in both examples (sürotla, mehribanliqla- fast, kind) are adverbs formed morphologically, 
that is, with the suffixes -la, -la. One of the main arguments for the accuracy of this idea is the questions that are asked to them. The postposition serving the expression of grammatical suffix or grammatical expression remains in the question asked. For example, atamla (with my father) - kim ilo?(with whom?) massin ila (with the car) - na ila? (with what?). In the given examples, the question is the question of the lexical unit, since $i l(-l a,-l a)$ in question, it is clear that it is not a grammatical category and that it fulfills the function of a lexical suffix. So, in those words, $-l a,-l a$ are not postpositions but lexical suffixes forming the adverb. It should be noted that almost in all works related to the adverb, - -la, - -l in this position are presented as adverb making suffix.

Though "ila" (with) postposition sometimes has a medium content, it cannot be at tool level. This case, in particular, shows itself when dealing with postposition, which is used with infinitive- non-conjugated form of verb. As it is well known, being of the medium at tool level for any deal is related with item, any action may be a medium for another action or process, but this cannot be named as a tool. For example: Yalniz gecə-gündüz oxumaqla istadiyina nail ola bilarsən. (You can only get what you want by reading day and night). Here the "oxumaqla" (by reading) is a medium that ensures the realization of the "nəticani aldə etmək olar" (achievement of the result). This function is created with the help of postposition.

There are expressions such as those that show more content than the medium itself. For example: Bu cür çallşmaqla istənilən nəticəni aldə etmak olmaz (With this kind of work, you cannot achieve the desired result.) The expression "bu cür çalısmaqla" (with this kind of work) in this sentence, the expression "gecə-gündüz oxumaqla" (reading day and night) in the previous sentence have the same feature formally, that is, from a grammatical point of view, that is, it both has infinitive composition and used with "ila" (with) postposition. But if in the first sentence, the medium content comes forefront, in the second the manner content is dominant. Let's also say that the formation of these different contents is related to the meaning of the word that these infinitives attach to self. In this case, the inner accent of the combination has a different characteristic; because in the first sentence the inner accent has fallen on the infinitive, the tool, medium content is stronger here, and in the second sentence, since the accent falls on the dependent component - word "bu cür" (this kind), the manner meaning passed to dominating position.

Let us note that in some works, - $-l a$, -la suffixes in the structure of originally adverb words are presented as a postposition $[6,9]$. For example: Biz zziyyztla, zülmls yaşamışıq. (We have lived with hardship, oppression.) Words "oziyyztla, zülmla" (with hardship, oppression) should not be called as noun with postposition. So, there is no concept of object here, on the other hand, the question that is asked on the words shows that there is no such content. The word with postposition requires the questions of kim ila?, nə ila? (with whom, with what). We do not observe it in these words. But these words can also be used as nouns with postpositions: Әziyyat ila, zülm ila çox şeya nail olmaq olar (through hardship, oppression many things can be achieved). Although the lexical meaning in the compared words is the same, the grammatical meaning is different; the manner is essential in the first, and the object content in the second.

5. One of the meanings expressed by the phrase "ila" (with) together with the word it attached to, is meaning of cause. At this point, it is synonymous with postpositions of the cause and objective. It is necessary to say that the initial potential content of this postposition is to express togetherness. There is no such word, phrase that this postposition is attached to, which does not contain content of togetherness. However, depending on the semantics of the words that this postposition applies to, as well as the lexical environment in which it encounters, other patterns are added, too. At that in one case the content of the togetherness acts as stabilized one- that is, the content of togetherness in one direction of development remains the main, leading content. In the second case, the development of new directions shows that we have the same manner meaning as one of them. Another semantic evolution is the occurrence and formation of the cause content in some cases. We come across this type of phrase in Kitabi-Dede Gorgut:

...Allah-taala xalqin alqış ila ona bir oğul verdi.(.. Almighty Allah gave him a son with the welcoming of the people.)

Here the phrase "xalqun alqış ila" (with the welcoming of the people) is the adverb of cause of the sentence, and requires "niyə?, nə üçün? (why?) question, however, the medium and the tool content are potentially self-manifested. The moving of tool, medium content backside is related with coming of cause content foreword.

It is possible to see this position of "ilə" (with) postposition in the modern spoken language. For example: Mon buraya sənin sözünla gəlmişəm (I came here with your word). In this sentence, the word "sözünla" (with your word) can be thought of forming the cause-objective content at first glance: nə üçün gəlmişəm? (why did I come?) However, the question is not logical because the cause-objective pattern here is potentially, and the tool, medium pattern is in the forefront.

6. In some works, it is shown that "ila" (with) postposition indicates "time object content". For example: İmran kişi ürəyindən keçanlari builki vaxtila tutuşdururdu [7, p. 298]. (Imran compared whatever were in his heart with this year time [7, p. 298].) As can be seen from the example, here although "ila" (with) postposition is used with word of time meaning (vaxtil), it does not express time meaning in the sentence with this expression, and express the object concept which we observed in other words. However, we also face the fact that this postposition expresses time concept in the spoken language. For example, Zamanı ila əmim da məni bu yoldan çəkindirmaya çalışmışdı. (Once my uncle tried to get me out of this way). The expression "zamant ila" (with time) is also used in the forms of "zamanla", or "zamaninda".

It should be noted that the phrase "vaxtl ila" ("with time") is also used instead of that expression. But the latter expression has also been formed in our modern language like an adverb: vaxtilo (once). Interestingly, in the last edition of the "Spelling dictionary of the Azerbaijani language", whereas the words "vaxtila, vaxtinda" (in time, timely) were recorded as independent lexical units, but words "zamanla, zamaninda" (in time, timely) were not given [8, p. 714]. In our opinion, these expressions, which were first formulated as words with postpositions, have now come into our vocabulary as independent words, so they should be included into the dictionary.

Let us note that it is clearly seen that this type of word in the poetic language of the great Azerbaijani poet I.Nasimi, who created his works in XIV - XV centuries, has a time conception: Man bu gün sabr eylasam, danla faqanı neylaram?! (When I endure today, why I need a dawn with cry? There the word "danla" used to explain "sabah" (tomorrow). The fact that these words with "ilo"(with) postposition expresses the concept of time is also observed in our modern dialects. 
7. When the "ila" (with) postposition is used with spatial words, different meanings emerge, most importantly, it expresses the place where the action takes place. For example: Meşa ila gedərkən atrafdan anlaşılmaz səslər eşidirdik (H.Mirələmov). (When we went through the forest, we heard unclear sounds around (H.Miralamov)). The expression "meşə ila"(through forest) in the example can also be replaced with the word "meşada" (in forest). Researchers have noted that when dealing with situations involving interconnection of cases and postpositions, in addition to passage of one of them to another, it draws attention that sometimes they perform the same function [9, p. 25].

It should be noted that the expression of a word with postposition the space context of action is directly related to the content of the action involved. In the example above, the phrase "meşa ila" (through the forest) since is related to the word "getmak" (go) of action context, the space is clearly manifested. This idea can be confirmed in other examples, too. For example: Axşam vaxt yol ila gedirdim (In the evening, I was walking on the road).

Conclusions. From the studies we have carried out, we can come to the conclusion that "ila" (with) postposition with a grammatical meaning creates many meaning patterns, which are:

1. Potentially forms the togetherness pattern.

2. "ila" (with) postposition may give tool, medium content to the word it attached to.

3. Some words that are used with the "ila" (with) postposition have the content of indirect object.

4. Sometimes, the manner can create a content pattern.

5. Can give a cause pattern to words it attached to.

6. In some works, it is indicated that "ila" (with) postposition means "time object content".

7. Expresses the concept of space, in which the action takes place.

\section{References:}

1. Migirin V.N. Essays on the theory of transitivity in the Russian language. Balti, 1971, p.162

2. Huseynzadeh M. Modern Azerbaijani language. Part III, Morphology, Baku : East-West, 2007, 280 pp.

3. Zeynalov F. Auxiliary speech parts in modern Turkish languages. Baku: Maarif 1971, $312 \mathrm{p}$.

4. Shukurov A. Historical grammar of Azerbaijani language. Baku: API publication, 1981, $100 \mathrm{p}$

5. Abdullayev A., Seyidov Y., Hasanov A. Modern Azerbaijani language. Part IV, Syntax. Baku: East-West, 2007, 424 p.
6. Manafov N.R., Behbudov J.M. Auxiliary speech parts in Azerbaijani language dialects and accents. Baku, 1992, $85 \mathrm{p}$.

7. Khalilov B. Morphology of modern Azerbaijani language. Part II, Baku: Adiloglu, 2003, 353 p.

8. Spelling dictionary of Azerbaijani language. Baku: East-West, 2013, 840 p.

9. Maitinskaya K.E. Official words in finno-ugric languages. Nauka, $1982,186 \mathrm{p}$.

Ахмедова А. А. Граматичні особливості постпозиції «з» в азербайджанській мові

Анотація. Постпозиції - це допоміжні частини мови, які історично склали самостійні слова. Перетворення самостійних слів на допоміжні слова супроводжується появою нових категоріальних значень. Перетворення однієї одиниці на іншу в мові, що постійно розвивається, є продуктом природного розвитку, і як результат, мова стає збагаченою та функціональнішою. Утворення допоміжних частин основних частин мови також $є$ частиною цього процесу.

Допоміжні частини мови не мають лексичного значення і не відповідають на запитання. Але воно має граматичне значення. Не бере участі у творенні слів.

Виникнення допоміжних частин мови, безумовно, пов'язане з виникненням абстракцій, більшою мотивацією мовного матеріалу в подальшому розвитку мови. Допоміжні частини мови виступають не лише як поєднання слів у реченні, але й утворюють різні граматичні значення, а також додають лексичному та семантичному змісту структурі, яку вони вводять. Це безпосередньо пов'язане з їх початковим положенням і призначенням.

Один і той же пост у функції може виражати різні значення. У цьому разі постпозиція пов'язана з тією ж подією і виконує ту ж функціонально-граматичну функцію і $є$ провідним змістом у своєму відношенні до будь-якого слова. У той же час значення відтінків у межах загального змісту також очевидно. 3 цього погляду розміщення «з» $є$ більш привабливим.

Постпозиція «з» може виражати багато значень залежно від контексту: 1. Це виражає контекст співіснування. 2. Забезпечує зміст методу зі словом у поєднанні. 3. Деякі слова, що вживаються у відміні «с», мають супровідний зміст. 4. Одним із значень, виражених постпозицією «з» у поєднанні зі словом, є значення причини. 5. Забезпечує «зміст об'єкта часу». 6. Обмінюючись словами з просторовим контекстом, виникають різні відтінки значення, головне - це поняття простору, в якому відбувається рух.

Ключові слова: граматичне значення, смислові ознаки, супровід, зміст часу. 